\title{
A structural model of millennial tourist behavior to- wards tourism in Davao Region
}

\author{
Hazel Princess M. Rebollo* \\ University of Mindanao, Davao City, Philippines
}

\author{
Keywords \\ Tourist behavior \\ Tourist visit intention \\ Tourist attitude \\ Tourist motivation \\ Social media
}

Received: 8 December 2017

Accepted: 5 January 2018

Published: 13 February 2018

\begin{abstract}
This study was conducted to theoretically develop and empirically test to explore the best fit model of millennial tourist behavior towards tourism in Davao Region, Philippines. Structural equation was utilized in this study to test the causal relationship between variables. A total of 553 survey questionnaires was collected from selected millennial tourist in Davao Region. The data were obtained at the pre-departure area of Davao City Airport and selected major tourism destinations of Davao Region. Descriptive statistics, Pearson $R$, Stepwise Regression, and Goodness of Fit Test were used to analyze the data. The results revealed that tourist attitude, tourist motivation, social media, tourist visit intention, and tourist behavior were all rated as moderately high. Furthermore, tourist attitude, tourist motivation, social media, and tourist visit intention were highly correlated with tourist behavior. Meanwhile, tourist visit intention and tourist attitude were the best predictor of tourist behavior while tourist motivation and social media were the least predictors. Furthermore, the final model passed all the goodness-offit indices criteria. The implication of these findings can be applied to the enhancement of tourism destination competitiveness.
\end{abstract}

(C) 2018 The Author(s). Published by TAF Publishing

\section{INTRODUCTION}

Tourism industry has long been recognized as one of the most influential economic sectors. It has been known that travel and tourism provide positive economic impact in most countries around the world. Nowadays, millennial are considered as the latest generation on the tourist markets, who are now active travelers wherein they are starting to build travel preferences, exhibiting trends, motivation, and influencing one's opinion and behavior. They share the same kind of experiences, but it comes to preferences and differences in behavior, attitudes, motivations, values, and lifestyles.

Many industries are interested to analyze the needs, preferences, drives, and influences of millennial people because they are considered as the new demographic driving consumerism (Saavedra, 2015). As Stein (2013) and Ordun (2015) mentioned that millennial are born from 1980 to 2000. There are about 80 million millennial in USA, young professionals and spend about $\$ 170$ billion on purchases each year (Murdough, 2016). In travel, 31\% of the millennial prioritize the travel activities than other aspects in life, and this group showed the most growth in travel transaction (Christoff, 2017).

On the other hand, Leask, Fyall, and Barron (2013) found out that plenty of company executives obtained negative or dismissive attitude towards millennial because they have difficulty in understanding their behavior (Vinerean, 2014; Kunnu, 2016). Li (2014) stated that the decision-making process in tourism has its weaknesses in explaining the millennial behavior mechanism. The tourism sector exerts efforts in making analysis in tourism acquisitions in order to understand the factors that influence the tourist. Hence, analyzing the tourism activities is complicated because tourists change their preferences, requirements, wants, and needs time to time (Loureiro \& Kastenholz, 2011).

Exploring the behavior of millennial tourists in any tourist attractions and activities may be of great help to all tourism providers and other related agencies in order to meet their

\footnotetext{
${ }^{*}$ Corresponding author: Hazel Princess M. Rebollo

†Email: rebollohp@gmail.com
} 
needs and they could be understood. Conversely, plenty of studies have been conducted in understanding the behavior of tourist but most of the authors used different forms of structural model in predicting tourist behavior. Other studies used one or two aspects which cannot suffice in providing a deep knowledge of how millennial tourists behave before, during, and after the tourism products' experiences. Despite the advantage of micro approaches, still, the overall picture of how millennial tourist behaves towards tourism products and services remains unclear. So, the researcher opted to explore the tourist millennial behavior by using the factors, like tourist visit intention, tourist attitude, tourist motivation, purchase intention, and social media, in order to bridge the existing gap of other researchers. The result of this undertaking may be added information which may be useful to the tourism industry.

\section{Objective of the Study}

The purpose of the study was to explore the best fit model of millennial tourist behavior towards tourism in Davao Region.

\section{Hypothesis of the study}

H1 There is no significant relationship and influence between tourist attitude, tourist motivation, social media, and tourist intention to tourist behavior.

\section{LITERATURE REVIEW}

\section{Tourist Attitude}

Zarrad and Debabi (2015) stated that attitude refers to the overall evaluation of individual behavior and attitudes that are affected by a set of social influences, like culture, references group, and family, especially on decision-making for a holiday destination (Rerkklang, 2017; Sirakaya \& Woodside, 2005). Parkany, Gallagher, and Viveiros (2004) emphasized that attitude is a part of travel decision process which includes attitudes, perceptions, and situations and event that leads to behavior. Tourists' attitude and feeling can change their traveling behavior which can affect their travel decision-making because attitude significantly influences tourists' intention to visit certain destination Albarq (2013). Phosikham, Vilayphone, Wayakone, and Phimmavong (2015) highlighted that tourist's attitude towards the destination is highly important for tourist destination because positive attitude from tourist towards destinations can bring tourist satisfaction.

\section{Tourist Motivation}

Motivation helps to activate and direct the behavior of one person Lien and Cao (2014) because it helps to recognize the specific desires, needs, and wants of a person which push them to act or behave in a specific way (Deci \& Ryan, 2000). Konu and Laukkanen (2009) stated that studying tourist motivation helps tourism sectors to understand why tourists are traveling and even to recognize the internal or external reason for visiting certain destination (Grimm \& Needham, 2012). Mengich et al. (2011) stressed out that obtaining accurate knowledge of travel motivation helps tourism marketing to understand tourist behavior which helps to come up with tourism marketing strategies and guidelines in attracting them and developed tourism demand.

\section{Social Media}

Social media is a good platform that can facilitate communication within the business to business and business to consumer relationship (Rafiee \& Sarabdeen, 2013). Social media provides empowerment to tourists to generate content through online communities, reviews, and recommendations. Social media is a tool to offer product globally and allow prospective consumers to praise/criticize the product (Hayta, 2013). In fact, most of the travelers used social media in their travel plan (Cahyanto, Pennington-Gray, Mandala, \& Schroeder, 2016). Ioanăs and Stoica (2014) added that tourist behavior is highly influenced by social media, particularly when there is degree of exposure of messages and the relation media, particularly the degree of exposure of messages and the relation created between the variety of information given and tourist who is about to make the purchase. Ozer (2012) revealed that the tourist buying decision is affected by the views and comments of their friends on social media. Social media are used by travelers in asking help, information, and suggestions before buying the product (Richard \& Guppy, 2014). Gretzel, Fesenmaier, and O'leary (2006) said that social media enable storytelling, a usual post-travel engagement in their travel culture, on a $24 / 7$ basis, not only to a larger audience but also provide a sense of belonging to virtual communities. Thus, social media are used as a tool for sharing of experiences and connection with others. However, some potential travelers depend their decision-making on other experiences due to the experimental nature of tourism products (Litvin, Goldsmith, \& Pan, 2008).

\section{Tourist's Visit Intention}

In tourism perspective, visit intentions refer to the tourist's judgment towards the destination. At the same time, it also helps to know their likeliness to revisit the same destination and willingness to recommend the destination to oth- 
ers. Destination image and satisfaction were two important variables that influenced visitors' intention (Som, Marzuki, Yousefi, \& AbuKhalifeh, 2012). Alizadeh and Saghafi (2014) found out that intention to visit or revisit a destination significantly leads to tourist loyalty toward the destination. Consequently, understanding the intention of the tourist is highly significant since the intention is based on the possible action of tourist's attitude. Tourist performs certain actions or methods in aiming the attitude. Thus, attitude is used to measure intention. Nevertheless, measuring the intention could be more accurate in predicting behavior than attitude (Li, 2014).

\section{Tourist's Behavior}

On the other hand, tourist behavior remains one of the most researched fields, with the terms travel behavior or tourist behavior (Cohen, Prayag, \& Moital, 2014). Vinerean (2014) stated that tourist's behavior comprises of tourist's intention, attitude, preferences, and decision regarding the behavior when purchasing products or services. Fratu (2011) added that tourist's behavior is a combination of actions, attitudes, and decisions regarding selecting, purchasing, and experiencing tourism products and services, and also its post-consuming reactions. On the other hand, Palani, Sohrabi, et al. (2013) stated that understanding tourist behavior helps to find the reasons and factors why the tourist chooses to experience the destination.

\section{Theoretical Framework}

This study was anchored on the Theory of Planned Behavior (Ajzen, 1991). The theory states that an individual's behavior is created by attitude, subjective norms, and perceived behavioral control, and attitude is transformed into behavior through the intention to act and this theory is also the predictor of one intention. Intentions are, in turn, predicted by attitudes about the behavior (Nisson \& Earl, 2015). Ajzen (1991) added that an individual's attitude is determined by behavioral belief, implying that cognitive motivation may influence affective attitude. Ozer (2012) considered social media as a new consumer behavior pattern because of the effective and efficient delivering of communication.

In relation to the study, the theory explains the behavior of millennial tourist towards tourism products and service stimulated by means of intentions. These intentions are influenced by attitude of their likelihood on the certain tourism products and services. Attitude is influenced by internal and external motivation to inspire tourists to travel. Moreover, social media are added to test the level of influence of technology that might change their behavior.

\section{RESEARCH MODEL}

Figure 1 presented the interrelationships between the independent variables as well as their causal relationships with the dependent variable, wherein tourist's visit intention, tourist's attitude, tourist's motivation, and social media are directly influencing tourist's behaviour.

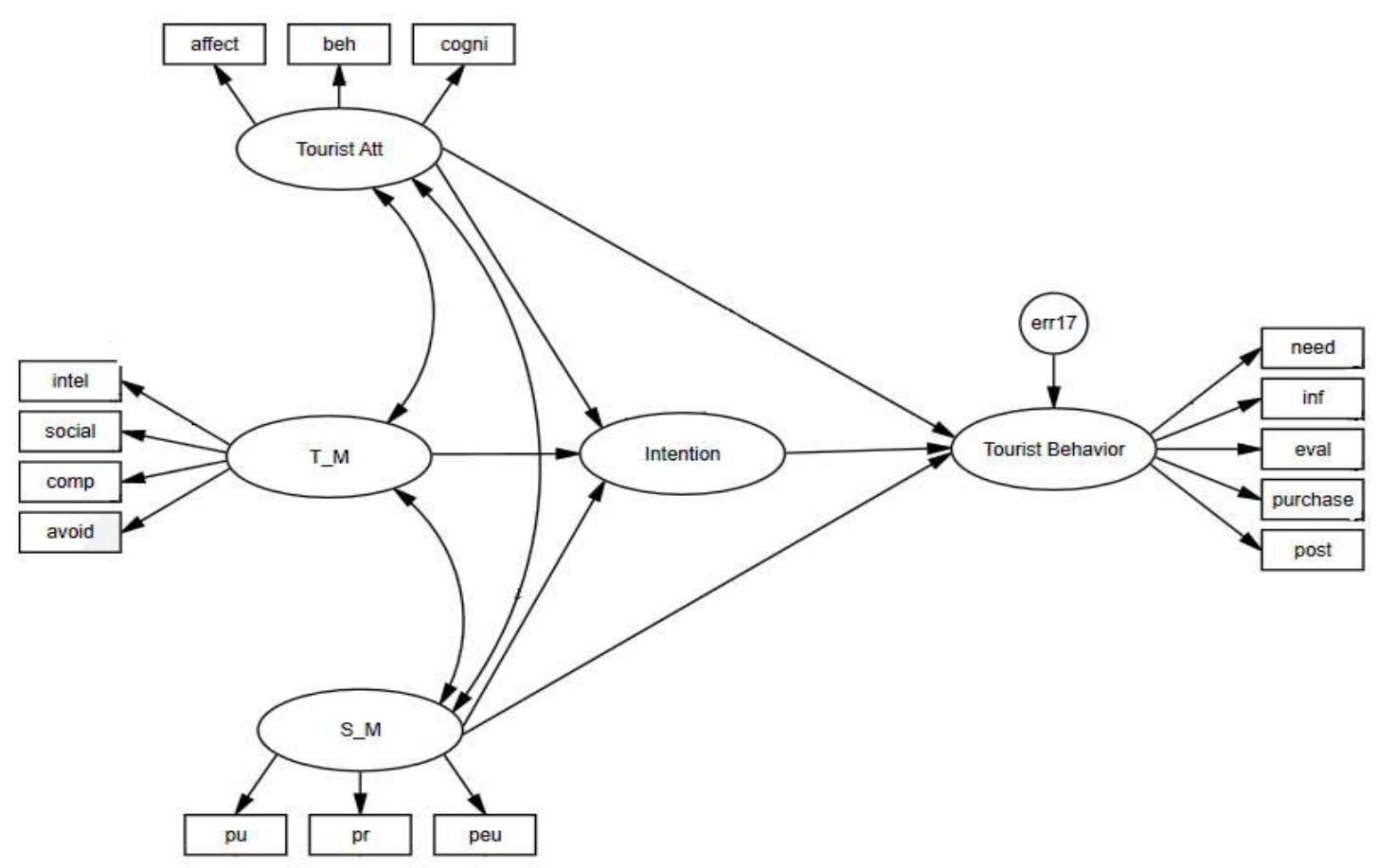

FIGURE 1. Research model 
In addition, tourist's attitude, social media, and tourist's visit intention are directly influencing tourist's behaviour while dependent variables are interrelated and interconnected to one another.

\section{METHODOLOGY}

This study utilized descriptive correlation method as the research design. Descriptive correlation is used to test the relationship of tourists' behaviors towards tourists' attitudes, tourists' motivation, social media, and tourists' visit intention towards tourism in Davao Region. A questionnaire was adopted and developed based on the similar research studies and the questions asked were of descriptive nature. The study was conducted in the four provinces of Davao Region namely: Compostela Valley, Davao del Norte, Davao Oriental, and Davao del Sur in order to obtain a wide and in-depth understanding on the tourist's behavior of millennial towards tourism in Region XI. The total sample size was 553 respondents with a $5 \%$ margin of error. The respondents were selected by using purposive sampling to ensure that only Filipino millennial tourists answered the research questionnaire. The statistical analysis included structural equation modeling, stepwise regression, goodness-of-fit test, Pearson r, mean, and standard deviation.

\section{DATA ANALYSIS}

Mean, Standard Deviation of Millennial Tourist Attitude, Motivation, Social Media, Intention, and Behavior

Table 1 explains the millennial tourist's attitude, motivation, social media, intention, and behavior. In terms of at- titude, millennial tourists formed a significant positive attitude particularly when the millennial tourists experience authentic destination and activities, perfect place to relax, allowing them to recreate and to establish and strengthen relationships, and there is a strong value of money.

Buffa (2015) also found out that millennial tourists choose a destination that is adventurous, entertaining, and offers relaxation, and they are even willing to spend more in order to ensure that they can unwind and experience authentic local activities (Redman, 2017) because they want comforts (Sheivachman, 2017) and great service and value of money (Redman, 2017).

Moreover, millennial tourists are highly motivated in taking trips because it helps to improve their intelligence, socialization, competencies, and it's one way for them to escape from hectic schedules. Millennial tourists agreed that travel is all about discovery and adventure. They see that travelling is an opportunity to explore and learn local cultural practices and to experience new things (David \& Gelfeld, 2015).

In the study conducted by Henry and Associates (2011), millennial do not take trips just because they want to travel but because they are looking for something that resonates with their need to make a difference. Mohammad and Som (2010) stated that millennial tourists visited places that increase their knowledge about the foreign destination, experience the different lifestyle and traditions, and see how the people of different cultures live. On the other hand, millennial tourists were highly influenced by social media because it is considered as most accessible and convenient in getting travel information.

TABLE 1. Mean, standard deviation of millennial tourist's attitude, motivation, social media, intention, and behavior towards tourism in Davao Region

\begin{tabular}{llll}
\hline \hline Item & Overall Mean & SD & Description Level \\
\hline \hline Tourist Attitude & 6.17 & .78 & Moderately High \\
Tourist Motivation & 6.24 & .74 & Moderately High \\
Social Media & 5.91 & .89 & Moderately High \\
Tourist Visit Intention & 5.92 & .88 & Moderately Likely \\
Tourist Behavior & 5.85 & .74 & Moderately Agree \\
\hline \hline
\end{tabular}

Almost all millennial have accounts on different social networking sites, and travel providers also use social media in promoting tourism destinations. Therefore, social media have significant contribution in stimulating the travel plan of millennial tourist. In fact, most of the millennial tourists are doing more travel research with an average of
10 sources before making travel decision (Swartz \& Huf, 2017). Swartz and Huf (2017) discovered that millennial know all of the best sites and methods to get the best travel deals. Millennial research thoroughly and evaluate the best tourism attractions (Tourism Commission, 2015). Social Media is one of the search engines being used by millennial 
tourists in searching information on the different tourism attractions because they widen their knowledge on different destinations and expand their travel options (Terttunen, 2017). Social media help millennial to read reviews, make comparison, verification, ask for opinions, and help them using various sources to obtain details before shaping any decisions (Singapore Tourism Board, 2013).

In addition, millennial tourist's visit intention is significantly high because tourists are attracted to the different tourism attractions due to the high and positive recommendations of their friends and the influence of social media. Reisinger and Mavondo (2006) stated that millennial tourists have a high intention to visit distant destinations because of the different attractions and culture. Dillon (2016) added that majority of the millennial tourists look first for the tourism destination through social media as a source of information feedback about the destination while other millennial travelers asked their friends and family members for suggestions on possible tourism destinations, accommodation, and tourism activities. EY's Global Real Estate Center (2014) found out that almost all millennial document their life experiences through social media, focusing on primarily funny, unique, inspiring or artistic content that can stir a response from their friends and followers and lead to influence others to try and experience the activity.

Lastly, millennial tourists positively behave from pre to post process of travel activities. This is because millennial has intention and aim to explore and experience the different tourism attractions and activities offered by Davao Region in order for them to learn something new and help to enhance their knowledge on tourism, and they are also attracted to experience the different travel destinations promoted through social media. Millennial also have some considerations in making a trip, such as price, accessibility, and activities offered by the destination. Hence, millennial opt to visit Davao Region again because it allows them to relieve their stress. Thus, tourism destinations in Davao Region meet the necessary preferences, requirements, and needs of millennial tourist.

As a matter of fact, millennial tourists are continually seeking for a big adventure, especially that millennial tourists have malady behavior of the Fear of Missing Out (FOMO) because they don't want to be left behind from others or in the trends. Millennial tourists visit the destinations because of the activities available, reputation of the destination, and the price of the activities has a good value (Sufahani, Ismail, \& Muhammad, 2013). Moreover, millennial aim to experience unique and interesting places, activities, culture, cuisine, and authentic way of local experiences that they could share with their friends and family (Rainbolt, 2015; TMS Family Travel Summit, 2016). David and Gelfeld (2015) figured out that millennial tourists used social media in sharing their positive and negative experiences on the destination they visited.

\section{Correlation of Tourism Behavior with Tourist Attitude, Tourist Motivation, Social Media, and Tourist's Visit In- tention}

Table 2 shows the relationship of millennial tourist's behavior towards tourist's attitude, tourist's motivation, social media, and tourist's visit intention. It can be observed that all the independent variables are significantly correlated with tourist's behavior. Correspondingly, tourist's behavior and tourist's attitude are also correlated with one another as reflected in correlation coefficient, $r=0.703^{* * *}$. This means that tourists' attitudes towards travelling are likely to influence travel behavior.

Becken (2003) emphasized that attitudes influence how tourists perceive a destination and how they plan their trip. Tourist's attitude can be measured by the destination's attributes and the overall destination's image (Cohen et al., 2014). Positive tourist attitudes have a higher plan in exploring the destination which is highly affected by tourist's behavior (Rai Technology University, 2017).

TABLE 2. Correlation of tourist's attitude, tourist's motivation, social media, and tourist's visit intention with tourist's behavior

\begin{tabular}{llll}
\hline \hline Independent Variable & $\boldsymbol{R}$ & \multicolumn{2}{c}{ Tourist Behavior } \\
\cline { 3 - 4 } & & $\boldsymbol{p}$-value & Remarks \\
\hline \hline Tourist's Attitude & $.703^{* * *}$ & .000 & Significant \\
Tourist's Motivation & $.623^{* * *}$ & .000 & Significant \\
Social Media & .613 & .000 & Significant \\
Tourist's Visit Intention & $.692^{* * *}$ & .000 & Significant \\
\hline \hline
\end{tabular}


On the other hand, tourist's behavior and tourist's motivation are significantly interrelated as seen in the correlation coefficient, $r=0.623^{* *}$. This implies that tourist's behavior is highly correlated with tourist's motivation. Behavior is driven by certain motivation (Prebensen, 2007). Travel motivation is driven by needs; these needs are an important element in understanding the tourist's behaviour (Makki, 2014). Thus, understanding the tourist motivation helps to know the tourist's interest, intention, and motives; the higher the tourist is motivated, higher is the interest to visit and get the experience of the destination (Consumer Behavior, 2017).

In addition, tourist behavior and social media are also correlated as observed in correlation coefficient, $r=0.613$. This implied that tourists' behaviors were related to social media. Social Media have become the most highly influencing factor for the tourist's behavior because it provides a platform not only for sharing information but also for tourist's experiences between other tourists. Thus, social media highly influence the behavior of the tourist.

Lastly, tourist's behavior is highly associated with tourist's intention as reflected by the correlation coefficient, $r=$ $0.692^{* * *}$. This implies that the higher the intent of millennial to visit, it increases the likelihood to trip. Lee, Lim, and Yong (2016) found out that tourist's behavior is affected by the intention.

The result becomes helpful in understanding the millennial behavior of tourist because it helps to answer when, where, why, and how tourists plan and arrange their trip through assessing the attitude, motivation, influence of social media, and travel intention. The way tourists choose the tourism products should be continuously researched in order to better understand, accept, and embrace the characteristics and values of this generation if they are to create and market relevant products and services that resonate with them and meet their needs. In addition, the tourism sectors may understand the behavior of millennial and other factors that influence the millennial in purchasing tourism products or services, to help tourism providers and operators to form a good marketing plan in meeting the tourism market demand. This can be concluded that tourists' behaviors are highly correlated with tourists' attitude, tourists' motivation, social media, and tourists' visit intention.

\section{Influence of Tourist's Attitude, Tourist's Motivation, So- cial Media, and Tourist's Visit Intention on Tourist's Be- havior}

Table 3 shows the stepwise regression analysis which focuses on the relationship between dependent variable and one or more independent variables. In this study, the dependent variable is the tourist's behavior while the independent variables are tourist's visit intention, tourist's attitude, tourist's motivation, and social media. Thus, the tourist's visit intention and tourist's attitude are the best predictors of tourist's behavior while tourist's motivation and social media are considered as weak predictors of tourist's behavior model.

In particular, it shows that tourist's visit intention and tourist's attitude have a positive standardized beta and highly influence tourist's behavior while tourist's motivation and social media unconstructively influence tourist's behavior. This means that the regression weight for tourist's attitude $(\beta=.283 ; p<.000)$ and tourist's visit intention $(\beta=.300 ; p<.000)$ fitted for the prediction of tourist's behavior. Thus, for every unit increase in predictor, there is a corresponding increase in behavior and it also positively and directly influences tourist's behavior while tourist's motivation and social media have a weak influence on tourist's behavior.

This implied that tourist's visit intention and tourist's attitude significantly influence tourist's behavior. It conforms with different studies that behavioral intention (Miao, 2015), and positive attitude (Njagi, Ndivo, \& Manyara, 2017) can influence tourists' behavior. Even, (Tsai \& Sakulsinlapakorn, 2016) said that motivation and social media (Altinay, Güçee, \& Bağ, 2017) positively and directly affect tourist's behavior.

TABLE 3. Influence of tourist's attitude, tourist's motivation, social media, and tourist's visit intention on tourist's behavior

\begin{tabular}{lllllll}
\hline \hline Independent Variable & \multicolumn{1}{c}{ Unstandardized Coefficients } & $\begin{array}{l}\text { Standardized } \\
\text { Coefficients }\end{array}$ & $\boldsymbol{t}$ & & $\boldsymbol{p}$-value & Remarks \\
\cline { 2 - 5 } & $\boldsymbol{\beta}$ & Std. Error & $\boldsymbol{\beta}$ & & \\
\hline \hline Constant & .927 & .183 & - & 5.064 & .000 & Significant \\
Tourist Attitude & .283 & .043 & .296 & 6.520 & .000 & Significant \\
Tourist Visit Intention & .300 & .033 & .353 & 9.162 & .000 & Significant \\
\hline \hline
\end{tabular}

Note: $R=.771, R$-square $=.594, F$-ratio $=268.087, p<.000$ 
Hence, most of the literature states that motivation and social media influence tourist's behavior. In fact, Som et al. (2012) affirmed that tourist's travel behavior is driven by internal and external motivations. Tourist decides to take a holiday trip because they want to fulfill their intrinsic desires. It is important to note that although motivation is only one of the various factors explaining tourist's behavior, its push and pull forces have been considered in influencing tourist's behavior (Njagi et al., 2017). Also, Mahika (2011) noted that motivational factors change over time in response to changes in the circumstances of individuals' personal life. On the other hand, each traveler is different and has different motivational factors. Thus, regardless of what motivates the tourist to travel, it is unlikely to influence the tourist's behavior as a whole.

In addition, Fotis (2015) said that social media are highly important for tourist's knowledge development which influences tourist's behavior. Especially, social media become tremendous in different ways and social media are considered as the effective means of information dissemination in tourist products and services. Wherein social media are highly involved in the travel process, that is, before, during, and after the travel. However, there are several factors affecting social media at all the stages of decision-making process which remains unclear (Fotis, 2015).

Lastly, the findings were apparent in the results of the regression analysis wherein $59.4 \%$ of the variance of tourist's behavior was explained by the two variables namely tourist's visit intention and tourist's attitude as indicated by $r$-square $=.594$. This means $40.6 \%$ of variation can be attributed to other factors. Thus, the result of the study contributes to the body of knowledge in the field of tourism sector.

\section{Goodness of FIT Measures of the Five Structural Models}

In this study, the researcher has come up with five models. The Table 3 shows the summary of the goodness of fit measures of the five structural models. Models 1 to 4 show the interrelationship between the independent variables as well as their causal relationship and the dependent variables. Hence, the models 1 to 4 were modified because all desired indices of goodness of fit measures were not met.

TABLE 4. Goodness of fit measures of the five structural models

\begin{tabular}{llllllll}
\hline \hline Model & CMIN/DF & $\boldsymbol{p}$-value & TLI & CFI & GFI & RMSEA & PCLOSE \\
\hline \hline 1 & 5.457 & .000 & .920 & .935 & .891 & .090 & .000 \\
2 & 5.943 & .000 & .919 & .936 & .892 & .090 & .000 \\
3 & 5.943 & .000 & .919 & .936 & .892 & .090 & .000 \\
4 & 3.734 & .000 & .951 & .965 & .934 & .070 & .000 \\
5 & 2.052 & .068 & .993 & .998 & .994 & .044 & .549 \\
\hline \hline
\end{tabular}

Criterion: CMIN/DF $<3, p$-value $>.05$, TLI $>.95, \mathrm{CFI}>.95, \mathrm{GFI}>.95, \mathrm{RMSEA}<.05$ to $.10, \mathrm{PCLOSE}>.05$

Furthermore, it can be gleaned that model 5 is the only structural model that passed all the desired criteria. The results show CMIN/DF $2.052<3$, $p$-value $.068>.05$, TLI .993 $>.95$, CFI $.998>.95$, GFI $.994>.95$, RMSEA $.044<.05$ to .10 , PCLOSE $.549>.05$, respectively. This implies that model 5 fits the data well and, therefore, as the best fit model of millennial tourist's behavior.

\section{Final Model Showing the Standardized Estimates}

Figure 2 is the modified model because four models came up unfit to the data. The primary task in the model-testing procedure was to determine the goodness-of-fit between the hypothesized model and the sample data. After performing the stepwise structural modeling, equation analysis yielded that the final model fit indices were found that all indices' results passed the criteria. The final model shows that the tourist's attitude and tourist's visit intention are only correlated with the endogenous variable which is tourist's behavior. In particular, tourist's attitude is strongly correlated ISSN: 2414-3111

DOI: $10.20474 /$ jahss-4.1.3 with tourist's visit intention ( $r=.73, p<.05)$ and tourist's behavior $(r=.75, p<.05)$. This means that the high rating in tourist's attitude also means a high rating in tourist's visit intention and tourist's behavior. Thus, tourist's behavior is highly influenced by tourist's attitude and tourist's visit intention.

Tourist's visit intention is also correlated with tourist's behavior ( $r=27$ ). Thus, the exogenous variables, namely tourist's visit intention and tourist's attitude, were significantly influencing one another. This denotes that for every unit increase in a certain variable, there is a corresponding increase in the correlated variable. On the other hand, there were also some variables that were uncorrelated, specifically tourist's motivation and social media. This means that with every unit decrease in the specific variable, there is a corresponding decrease also in the other variable. This might be the reason that the used variables did not perfectly correlate with one another.

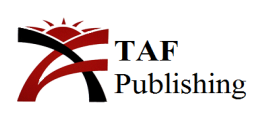




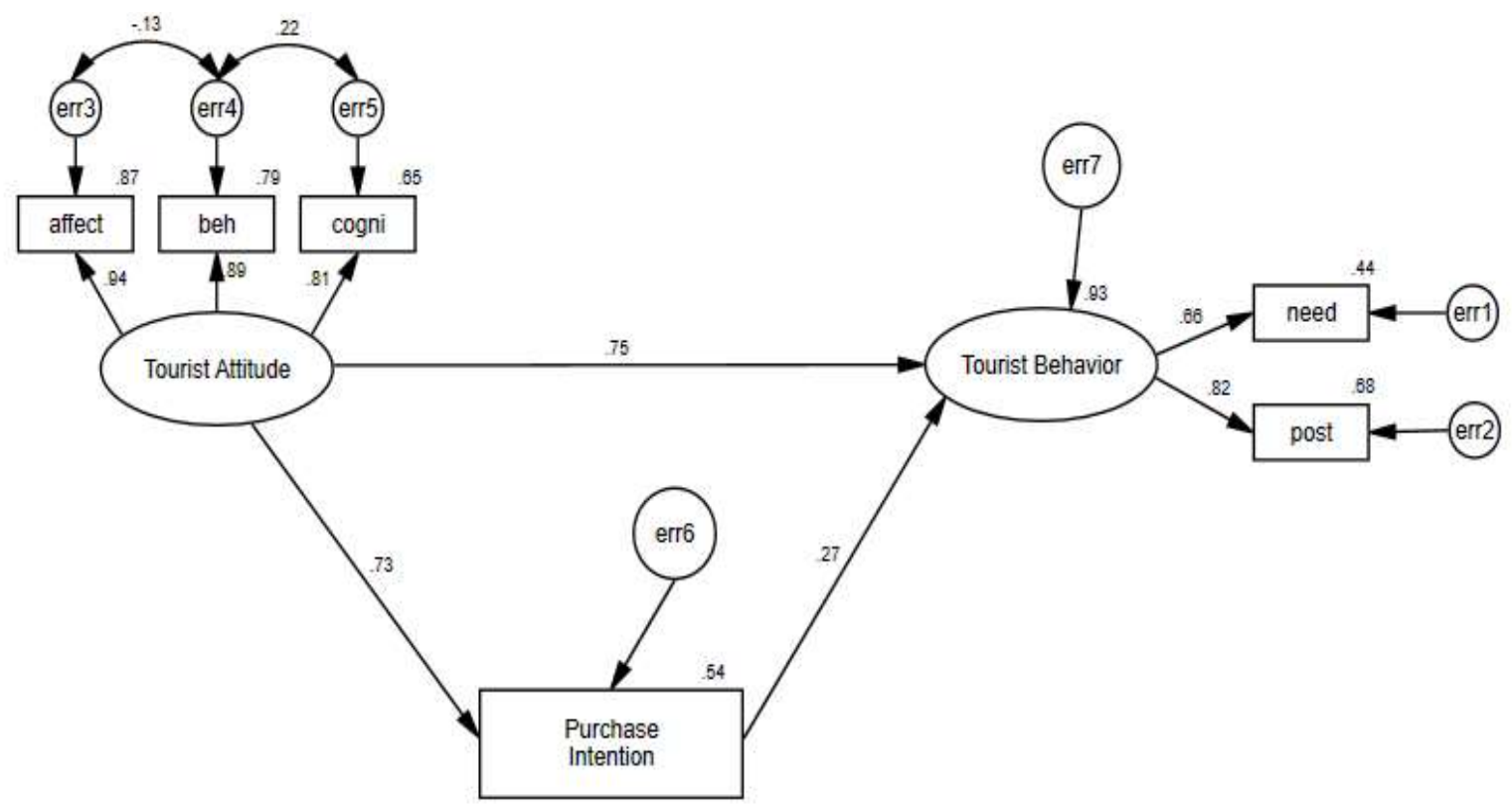

FIGURE 2. Final Model showing the standardized estimates

\section{CONCLUSION}

This can be concluded that tourist's attitude, tourist's motivation, social media, and tourist's visit intention are highly correlated with millennial tourist's behavior. Hence, tourist's attitude and tourist's visit intention are the best predictors of millennial tourist's behavior. Thus, the way tourists choose the tourism products should be continuously researched in order to better understand, accept, and embrace the characteristics and values of this generation if they are to create and market relevant products and services that resonate with them and meet their needs. In addition, the tourism sectors may understand the behavior of millennial and other factors that influence the millennial in purchasing tourism products or services, to help tourism providers and operators to form a good marketing plan in meeting the tourism market demand.

\section{LIMITATIONS AND RECOMMENDATIONS}

The selection of respondents is a limitation of the study. Hence, future research may focus on more diversified respondents to verify the findings of the current study and use in other geographic areas with larger sample population to obtain more accurate results. Lastly, future researcher may continually explore the use of variable in other group parameters to test its goodness of fit of the model and to add body of knowledge in the tourism sector.

\section{REFERENCES}

Ajzen, I. (1991). The theory of planned behavior. Organizational Behavior and Human Decision Processes, 50(2), 179-211. doi:https://doi.org/10.4135/9781412952576.n208

Albarq, A. N. (2013). Measuring the impacts of online word-of-mouth on tourists' attitude and intentions to visit Jordan: An empirical study. International Business Research, 7(1), 14-22. doi:https://doi.org/10.5539/ibr.v7n1p14

Alizadeh, A., \& Saghafi, G. (2014). An examination of antecedents of loyalty intention to travel: The case of Malaysia. In Proceedings of the 1st Middle East Conference on Global Business, Economics, Finance and Banking, Dubai, United Arab Emirates.

Altinay, M., Güçee, E., \& Bağ, C. (2017). Consumer behavior in the process of purchasing tourism product in social media. Journal of Business Research-Turk, 9(1), 381-402. doi:https://doi.org/10.20491/isarder.2017.250

Becken, S. (2003). An integrated approach to travel behaviour with the aim of developing more sustainable forms of tourism. In Landcare Research Internal Report, Landcare Research, Lincoln, New Zealand.

Buffa, F. (2015). Young tourists and sustainability. profiles, attitudes, and implications for destination strategies. Sustainability, 7(10), 14042-14062. doi:https://doi.org/10.3390/su71014042 
Cahyanto, I., Pennington-Gray, L., Mandala, L., \& Schroeder, A. (2016). The effects of social media usage on travel information searching and travel experience sharing. Tourism Travel and Research Association: Advancing Tourism Research Globally, 42, 1-8.

Christoff, J. (2017). Millennial travel spending experiences growth spurt. Westampton, NJ: Travel Pulse.

Cohen, S. A., Prayag, G., \& Moital, M. (2014). Consumer behaviour in tourism: Concepts, influences and opportunities. Current Issues in Tourism, 17(10), 872-909. doi:https://doi.org/10.1080/13683500.2013.850064

Consumer Behavior. (2017). Consumer behavior: The psychology of marketing. Retrieved from https : //bit . 1y/2xYPFey David, P., \& Gelfeld, V. (2015). Travel research: 2016 travel trends (Tech. Rep.). Washington, DC, WA: AARP Research.

Deci, E. L., \& Ryan, R. M. (2000). The "what" and "why" of goal pursuits: Human needs and the self-determination of behavior. Psychological Inquiry, 11(4), 227-268. doi:https://doi.org/10.1207/s15327965pli1104_01

Dillon, B. (2016). Marketing travel to millennials: Is social media the ticket? (Unpublished doctoral dissertation). School of Journalism and Mass Communication, University of Minnesota, Minneapolis, MN.

EY's Global Real Estate Center. (2014). Global hospitality insights (Tech. Rep.). London, UK: Ernst \& Young Global Limited.

Fotis, J. N. (2015). The use of social media and its impacts on consumer behaviour: The context of holiday travel (Unpublished doctoral dissertation). Bournemouth University, Dorset, UK.

Fratu, D. (2011). Factors of influence and changes in the tourism consumer behaviour. In Bulletin of the Transilvania University of Brasov, Transilvania University Press, Brasov, Romania.

Gretzel, U., Fesenmaier, D. R., \& O’leary, J. T. (2006). The transformation of consumer behaviour. In Tourism business frontiers, Routledge, Abingdon, UK. doi:https://doi.org/10.1016/b978-0-7506-6377-9.50009-2

Grimm, K. E., \& Needham, M. D. (2012). Moving beyond the "I" in motivation: Attributes and perceptions of conservation volunteer tourists. Journal of Travel Research, 51(4), 488-501. doi:https://doi.org/10.1177/0047287511418367

Hayta, A. B. (2013). A study on the of effects of social media on young consumers' buying behaviors. European Journal of Research on Education, Special Issue: Human Resource Management, 65-74.

Henry, J., \& Associates. (2011). Meet the millennials: Insights for destinations (Tech. Rep.). St. Louis, MO: Delaware North Companies Parks \& Resorts and PGAV Destinations.

Ioanăs, E., \& Stoica, I. (2014). Social media and its impact on consumers behavior. International Journal of Economic Practices and Theories, 4(2), 295-303.

Konu, H., \& Laukkanen, T. (2009). Roles of motivation factors in predicting tourists' intentions to make wellbeing holidaysA Finnish case. In Australian and New Zealand Marketing Academy Annual Conference 2009, Melbourne, Australia.

Kunnu, W. (2016). Foreign tourists' satisfaction towards selecting the accommodation service (hostel) in Bangkok. International Journal of Humanities, Arts and Social Sciences, 2(1), 40-44. doi:https://doi.org/10.20469/ijhss.2.20004-1

Leask, A., Fyall, A., \& Barron, P. (2013). Generation Y: Opportunity or challenge-strategies to engage Generation Y in the UK attractions' sector. Current Issues in Tourism, 16(1), 17-46. doi:https://doi.org/10.1080/13683500.2011.642856

Lee, J. H., Lim, K. F., \& Yong, K. Y. (2016). Factors influencing purchase intention towards dietary supplement products among young adults (Tech. Rep.). Perak, Malaysia: Universiti Tunku Abdul Rahman.

Li, Y.-M. (2014). Effects of story marketing and travel involvement on tourist behavioral intention in the tourism industry. Sustainability, 6(12), 9387-9397. doi:https://doi.org/10.3390/su6129387

Lien, C. H., \& Cao, Y. (2014). Examining wechat users' motivations, trust, attitudes, and positive word-of-mouth: Evidence from China. Computers in Human Behavior, 41, 104-111. doi:https://doi.org/10.1016/j.chb.2014.08.013

Litvin, S. W., Goldsmith, R. E., \& Pan, B. (2008). Electronic word-of-mouth in hospitality and tourism management. Tourism Management, 29(3), 458-468. doi:https://doi.org/10.1016/j.tourman.2007.05.011

Loureiro, S. M. C., \& Kastenholz, E. (2011). Corporate reputation, satisfaction, delight, and loyalty towards rural lodging units in Portugal. International Journal of Hospitality Management, 30(3), 575-583. doi:https://doi.org/10.1016/ j.ijhm.2010.10.007

Mahika, E.-C. (2011). Current trends in tourist motivation. Cactus Tourism Journal, 2(2), 15-24.

Makki, F. (2014). Influence of branding on consumer behavior: Case of Palais Hansen Kempinski Vienna (Unpublished master's dissertation). Modul University Vienna, Vienna, Austria.

Mengich, O. C., et al. (2011). Township tourism: Understanding tourist motivation (Unpublished doctoral dissertation). University of Pretoria, Pretoria, South Africa. 
Miao, Y. (2015). The influence of electronic-wom on tourists' behavioral intention to choose a destination: A case of Chinese tourists visiting Thailand. Assumption University-Graduate School of Business e-Journal, 8(1), 13-31.

Mohammad, B. A. M. A.-H., \& Som, A. P. M. (2010). An analysis of push and pull travel motivations of foreign tourists to Jordan. International Journal of Business and Management, 5(12), 41-50. doi:https://doi.org/10.5539/ijbm.v5n12p41

Murdough, C. (2016). How millennials make purchase decisions today. San Francisco, CA: Affirm Inc.

Nisson, C., \& Earl, A. (2015). The theories of reasoned action and planned behavior: Examining the reasoned action approach to prediction and change of health behaviors. In K. Sweeny \& M. Robbin (Eds.), The wiley encyclopedia of health psychology. Hoboken, NJ: John Wiley \& Sons.

Njagi, C. W., Ndivo, R. M., \& Manyara, G. (2017). Understanding the travel motivation among youth travelers in Kenya: The 'push' and 'pull' paradigm. African Journal of Hospitality, Tourism and Leisure, 6(1), 1-16.

Ordun, G. (2015). Millennial (Gen Y) consumer behavior their shopping preferences and perceptual maps associated with brand loyalty. Canadian Social Science, 11(4), 40-55.

Ozer, S. (2012). The effect of social media on consumer buying decision process (Unpublished doctoral dissertation). National College of Ireland, Dublin, Ireland.

Palani, S., Sohrabi, S., et al. (2013). Consumer attitudes and behavior when selecting a holiday destination: Introducing Kurdistan to the Finnish traveler (Unpublished master's thesis). Business Economics and Tourism, Vaasa, Finland.

Parkany, E., Gallagher, R., \& Viveiros, P. (2004). Are attitudes important in travel choice? Transportation Research Record: Journal of the Transportation Research Board (1894), 127-139. doi:https://doi.org/10.3141/1894-14

Phosikham, T., Vilayphone, A., Wayakone, S., \& Phimmavong, S. (2015). Tourists' attitudes towards tourism development and heritage preservation in the world heritage town of Luang Prabang, Lao PDR. International Journal of Business and Social Science, 6(8), 37-45.

Prebensen, N. K. (2007). A grammar of motives for understanding individual toursit behaviour (Unpublished doctoral dissertation). Norwegian School of Economics and Business Administration, Bergen, Norway.

Rafiee, V. B., \& Sarabdeen, J. (2013). Social media marketing: The unavoidable marketing management tool (Unpublished doctoral dissertation). University of Wollongong, Wollongong, Australia.

Rai Technology University. (2017). Understanding consumer behaviour. Rai Technology University, Bangalore, India. Retrieved from https://bit.1y/2v3hZLo

Rainbolt, D. (2015). How the millennial generation is changing the way we travel. Retrieved from https : //bit. ly/2NEo3BK

Redman, J. (2017). Tomorrow's traveller millennials and the future of business travel (Tech. Rep.). London, UK: SACO.

Reisinger, Y., \& Mavondo, F. (2006). Cultural differences in travel risk perception. Journal of Travel \& Tourism Marketing, 20(1), 13-31. doi:https://doi.org/10.1300/j073v20n01_02

Rerkklang, P. (2017). Thailand tourism images and behaviors of Thai people in Bangkok and Metropolitan. International Journal of Humanities, Arts and Social Sciences, 3(3), 122-128. doi:https://doi.org/10.20469/ijhss.3.20004-3

Richard, J. E., \& Guppy, S. (2014). Facebook: Investigating the influence on consumer purchase intention. Asian Journal of Business Research, 4(2), 1-10. doi:https://doi.org/10.14707/ajbr.140006

Saavedra, K. P. (2015). Millennials as travelers. Makati City, Philippines: BusinessMirror.

Sheivachman, A. (2017). US millennials travel the most but Gen Z is on the rise. Retrieved from https://bit. Iy/2f JzNaP

Singapore Tourism Board. (2013). Navigating the next phase of tourism growth. In Tourism Industry Conference, New Delhi, India.

Sirakaya, E., \& Woodside, A. G. (2005). Building and testing theories of decision making by travellers. Tourism Management, 26(6), 815-832. doi:https://doi.org/10.1016/j.tourman.2004.05.004

Som, A. P. M., Marzuki, A., Yousefi, M., \& AbuKhalifeh, A. N. (2012). Factors influencing visitors' revisit behavioral intentions: A case study of Sabah, Malaysia. International Journal of Marketing Studies, 4(4), 39-50. doi:https://doi.org/10.5539/ ijms.v4n4p39

Stein, J. (2013). Millennials: The me me me generation. Time Magazine, 20, 1-8. doi:https://doi.org/10.1057/ 9781137375940.0010

Sufahani, S. F., Ismail, Z., \& Muhammad, M. (2013). An analysis of international tourist behavior towards tourism sector in Kelantan. In Prosiding Seminar Kebangsaan Aplikasi Sains dan Matematik 2013 (SKASM 2013), Batu Pahat, Johor. 
Swartz, L., \& Huf, S. (2017). Getting to know Gen Z: How the pivotal generation is different from millennials (Tech. Rep.). Arizona, AZ: Barkley, Inc. and FutureCast, LLC.

Terttunen, A. (2017). The influence of instagram on consumers' travel planning and destination choice (Unpublished master's thesis). Haaga-Helia University of Applied Sciences, Porvoo, Finland.

TMS Family Travel Summit. (2016). Connecting with millennials, the new family traveler (Tech. Rep.). South Walton, FL: TMS Family Travel Summit.

Tourism Commission. (2015). Canada millennial domestic travel summary report (Tech. Rep.). Vancouver, Canada: CTC Research.

Tsai, L. M., \& Sakulsinlapakorn, K. (2016). Exploring tourists' push and pull travel motivations to participate in songkran festival in Thailand as a tourist destination: A case of Taiwanese visitors. Journal of Tourism and Hospitality Management, 4(5), 183-197. doi:https://doi.org/10.17265/2328-2169/2016.10.001

Vinerean, A. (2014). Consumption habits during the decision making process in tourism. Expert Journal of Business and Management, 2(2), 47-53.

Zarrad, H., \& Debabi, M. (2015). Analyzing the effect of electronic word of mouth on tourists' attitude toward destination and travel intention. International Research Journal of Social Sciences, 4(4), 53-60. 